Politics and Development in the Caribbean Basin 


\section{Politics and Development in the Caribbean Basin}

Central America and the Caribbean in the New World Order

Jean Grugel

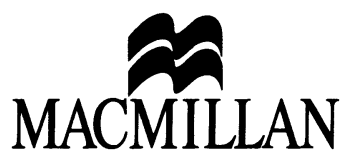


All rights reserved. No reproduction, copy or transmission of this publication may be made without written permission.

No paragraph of this publication may be reproduced, copied or transmitted save with written permission or in accordance with the provisions of the Copyright, Designs and Patents Act 1988, or under the terms of any licence permitting limited copying issued by the Copyright Licensing Agency, 90 Tottenham Court Road, London W1P 9HE.

Any person who does any unauthorized act in relation to this publication may be liable to criminal prosecution and civil claims for damages.

First published 1995 by MACMILLAN PRESS LTD

Houndmills, Basingstoke, Hampshire RG21 2XS

and London

Companies and representatives

throughout the world

ISBN 978-0-333-57305-1 ISBN 978-1-349-23975-7 (eBook)

DOI 10.1007/978-1-349-23975-7

A catalogue record for this book is available from the British Library.

$\begin{array}{rrrrrrrrrr}10 & 9 & 8 & 7 & 6 & 5 & 4 & 3 & 2 & 1 \\ 04 & 03 & 02 & 01 & 00 & 99 & 98 & 97 & 96 & 95\end{array}$

Copy-edited and typeset by Povey-Edmondson

Okehampton and Rochdale, England 
Para Victor Silvio, con amor 


\section{Contents}

List of Tables

viii

Abbreviations $\quad \mathrm{x}$

Map of Central America and the Caribbean Basin xii

Introduction: The Caribbean Model of Development 1

1. The Historical Evolution of the Caribbean Basin 29

2. Making Politics: Class, Ethnicity and Nation 61

3. The Political Systems of the Region 94

4. The International Relations of the Caribbean Basin 125

5. Regional Development 159

6. Revolution: Cuba, Nicaragua and Grenada 196

Conclusion: Is the Crisis Over? 232

Guide to Further Reading 244

Bibliography 249

$\begin{array}{ll}\text { Index } & 261\end{array}$ 


\section{List of Tables}

I.1 Central America and the Caribbean: population and territorial extension

I.2 Social profile of the region

I.3 Human development index: Central America and the Caribbean

I.4 Unemployment in Central America and the Caribbean (1992)

I.5 GDP (US\$) and growth of GDP (1992) 27

I.6 Urban population: Central America (1992) 28

I.7 Density of population (1991) 28

1.1 Sugar production, 1730-91 50

1.2 Sugar production, 1815-94 55

2.1 Distribution of national income in selected Central American countries in $1989 \quad 68$

2.2 Percent of national income controlled by the top 10 per cent of the population (selected countries)

3.1 US military and economic assistance to Costa Rica, 1988 and 1989

4.1 US assistance to Central America, 1980-6

4.2 Per capita income in Central America, 1980 and 1984

4.3 Lome Caribbean trade with the EU and the world (selected countries)

4.4 Financial flows to Central America according to region

4.5 Central American exports by area

4.6 CACM and CARICOM: inter-regional exports as percentage of total exports

5.1 Food imports as percentage of total imports 168

5.2 Annual growth of GDP (selected countries) 183

5.3 GDP growth, 1990 and 1991 (selected countries) 184 
List of Tables ix

6.1 Agricultural production in Nicaragua, 1977-8 and 1981-2 213

6.2 Land ownership in Nicaragua 215

C.1 Military spending (selected countries) 


\section{Abbreviations}

ACP

ARENA

CACM

CARICOM

CBI

CDR

CIS

CUC

ECLA/ECLAC

DLP

EGP

EU

FDR

FMLN

FSLN

GATT

IMF

JLP

NAFTA

NJM

OAS

OECS

PCN

PDC

PDP

PL
African, Caribbean and Pacific countries

Alianza Republicana Nacionalista (El Salvador)

Central American Common Market

Caribbean Community and Common Market

Caribbean Basin Initiative

Committee for the Defence of the Revolution

(Cuba)

Commonwealth of Independent States

Comité de Unidad Campesina (Guatemala)

Economic Commission for Latin America/

Economic Commission for Latin America and the Caribbean

Democratic Labour Party (Trinidad and Tobago)

Ejército Guerillero de los Pobres (Guatemala)

European Union

Frente Democrático Revolucionario (El

Salvador)

Frente Farabundo Martí para la Liberación

Nacional (El Salvador)

Frente Sandinista de Liberación Nacional

(Nicaragua)

General Agreement on Tariffs and Trade

International Monetary Fund

Jamaican Labour Party

North American Free Trade Area

New Jewel Movement (Grenada)

Organization of American States

Organization of Eastern Caribbean States

Partido de Conciliación Nacional (El Salvador)

Partido Democrata Cristiano (El Salvador)

Popular Democratic Party (Puerto Rico)

Partido Liberal (Honduras) 


$\begin{array}{ll}\text { PLN } & \text { Partido de Liberación Nacional (Costa Rica) } \\ \text { PN } & \begin{array}{l}\text { Partido Nacional (Honduras) } \\ \text { PNM }\end{array} \\ \text { People's National Movement (Trinidad and } \\ \text { Tobago) } \\ \text { PNP } & \text { New Progressive Party (Puerto Rico) } \\ \text { PR } & \text { Partido Reformista (Dominican Republic) } \\ \text { PRD } & \text { Partido Revolucionario Dominicano (Dominican } \\ & \text { Republic) } \\ \text { PRG } & \text { People's Revolutionary Government (Grenada) } \\ \text { PRUD } & \text { Partido Revolucionario de Unifiacacion } \\ & \text { Democrática (El Salvador) } \\ \text { PSD } & \text { Partido Social Democrata (Costa Rica) } \\ \text { PUSC } & \text { Partido Unidad Social Cristiano (Costa Rica) } \\ \text { ULF } & \text { United Labour Front (Trinidad and Tobago) } \\ \text { UNO } & \text { Unión Nacional de la Oposición (Nicaragua) } \\ \text { USAID } & \text { US Agency for International Development }\end{array}$




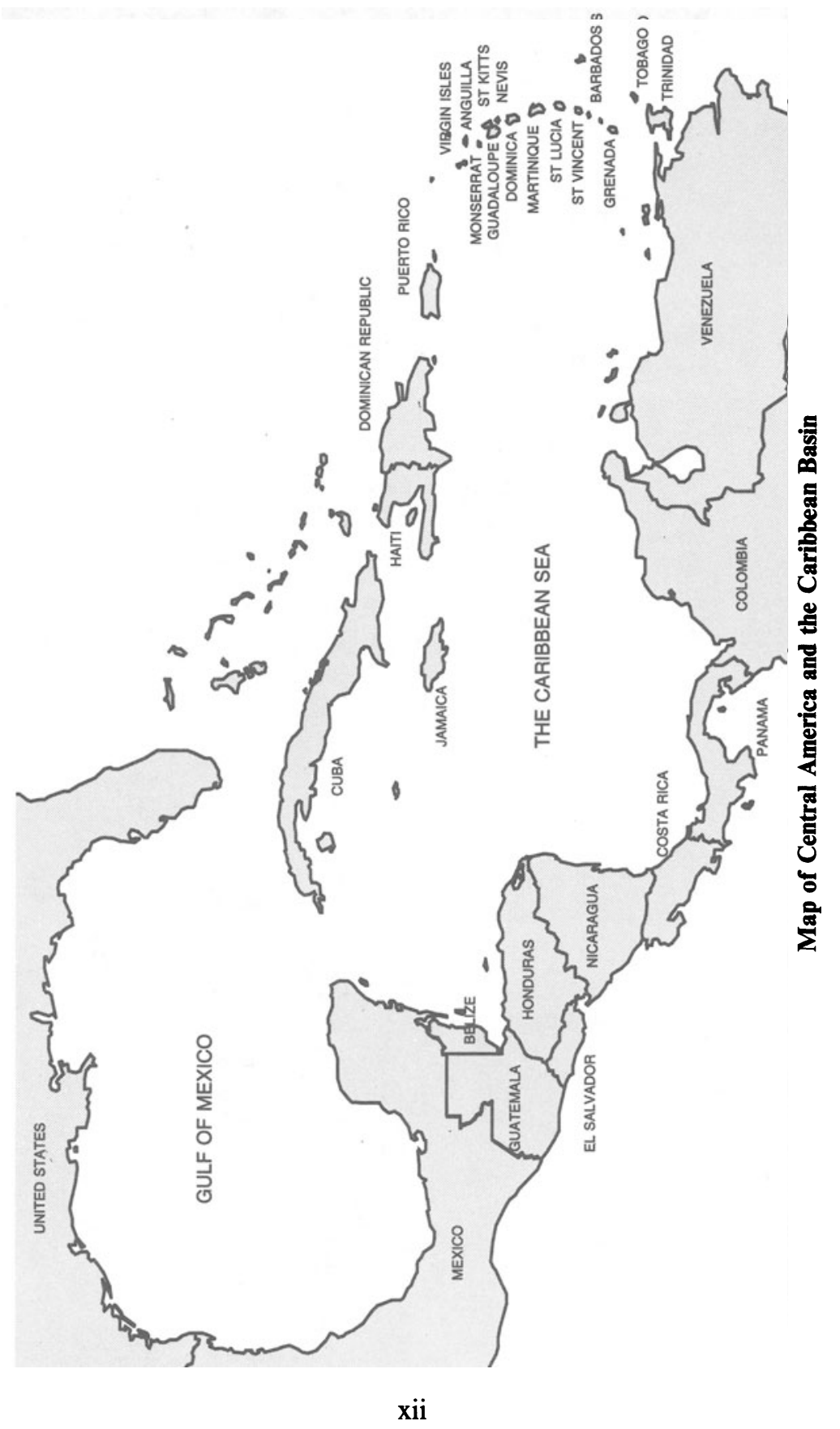

